\title{
Education and Outreach in the Life Sciences - Quantitative Analysis Report
}

RL Burkbank (PNNL)

LV John (Battelle)

HA Mahy (PNNL)
S Wijesinha Rose (Battelle)

RE Weller (PNNL)

A Nelson-Wally (Battelle)

October 2008

Pacific Northwest

NATIONAL LABORATORY

Proudly Operated by Battelle Since 1965 


\title{
DISCLAIMER
}

This report was prepared as an account of work sponsored by an agency of the United States Government. Neither the United States Government nor any agency thereof, nor Battelle Memorial Institute, nor any of their employees, makes any warranty, express or implied, or assumes any legal liability or responsibility for the accuracy, completeness, or usefulness of any information, apparatus, product, or process disclosed, or represents that its use would not infringe privately owned rights. Reference herein to any specific commercial product, process, or service by trade name, trademark, manufacturer, or otherwise does not necessarily constitute or imply its endorsement, recommendation, or favoring by the United States Government or any agency thereof, or Battelle Memorial Institute. The views and opinions of authors expressed herein do not necessarily state or reflect those of the United States Government or any agency thereof.

\author{
PACIFIC NORTHWEST NATIONAL LABORATORY \\ operated by \\ BATTELLE \\ for the \\ UNITED STATES DEPARTMENT OF ENERGY \\ under Contract DE-AC05-76RL01830 \\ Printed in the United States of America \\ Available to DOE and DOE contractors from the \\ Office of Scientific and Technical Information, \\ P.O. Box 62, Oak Ridge, TN 37831-0062; \\ ph: (865) 576-8401 \\ fax: $(865) 576-5728$ \\ email: reports@adonis.osti.gov
}

Available to the public from the National Technical Information Service

5301 Shawnee Rd., Alexandria, VA 22312 ph: (800) 553-NTIS (6847)

email: orders@ntis.gov <http://www.ntis.gov/about/form.aspx>

Online ordering: http://www.ntis.gov

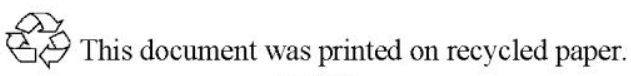

(8/2010) 


\title{
Education and Outreach in the Life Sciences - Quantitative Analysis Report
}

\author{
RL Burkbank (PNNL) S Wijesinha Rose (Battelle) \\ LV John (Battelle) \\ RE Weller (PNNL) \\ HA Mahy (PNNL) \\ A Nelson-Wally (Battelle)
}

October 2008

Prepared for

the U.S. Department of Energy

under Contract DE-AC05-76RL01830

Pacific Northwest National Laboratory

Richland, Washington 99352 



\section{Contents}

1.0 Introduction ............................................................................................. 1

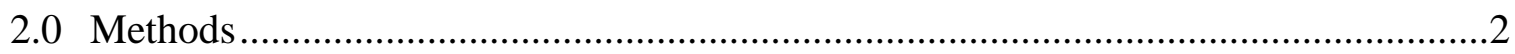

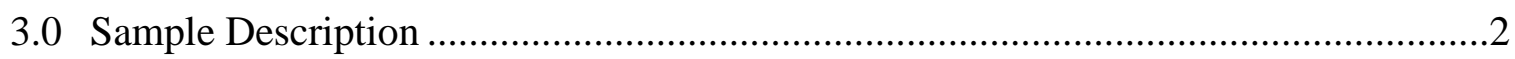

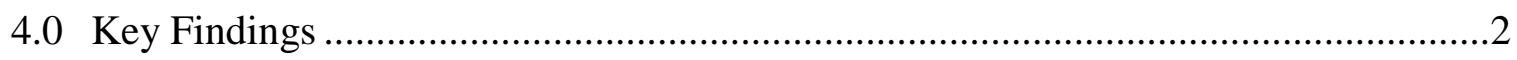

4.1 Biosafety Awareness and Experience (Questions 4-10) ........................................ 2

4.22006 Outreach and Education Training (Questions 11-24) ................................... 3

4.3 Publication and Journal Review (Questions 26-34) ............................................ 3

4.4 Minimizing Threat to National Security (Questions 38-61) ................................. 3

4.4.1 Role and Responsibilities of Scientists (Questions 38-42)...................... 3

4.4.2 Access to Agents and Equipment (Questions 45-46) ............................ 4

4.4.3 Research Findings (Questions 49-52) .............................................. 4

4.4.4 Training (Questions 55-57) .............................................................. 4

4.4.5 Review and Funding (Questions 60-61) ............................................ 4

4.5. Opinions about Bioterrorism and Dual-Use Research (Questions 64-73) ........... 4

5.0 Conclusions and Recommendations........................................................................................5

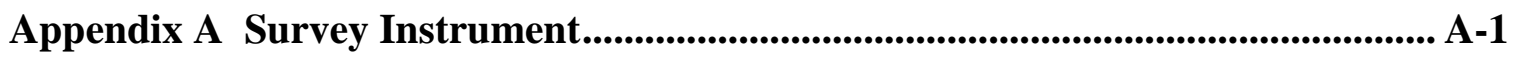

Appendix B Survey Answers........................................................................................B-1 



\subsection{Introduction}

Rapid developments in biotechnology and the life sciences bring significant benefits but also create new security challenges. In recent years, members of the scientific and security policy communities have raised concerns about the potential for misuse of knowledge, tools, and techniques for purposes of bioterrorism. Such research is sometimes called "dual-use" research because, although the research is intended for beneficial purposes only, it could be misapplied. The role of scientists, institutions, scientific societies, and the government is critical in fostering an environment that enhances both the scientific enterprise and national security.

In 2004, the U.S. government established the National Science Advisory Board on Biosecurity (NSABB) under the auspices of the National Institutes of Health to contemplate the possibility and impact of greater oversight for life sciences research to prevent or mitigate deliberate misuse. Similarly, the U.S. Department of Energy (DOE) is considering how to respond to emerging issues of concern related to dual-use. Other Federal agencies are planning to issue further guidelines and are considering additional policies regarding responsible scientific research. Discussion sessions on this topic were also conducted by PNNL for the DOE's Office of International Regimes and Agreements (NA-243) at nine of the national laboratories in Fall 2006.

The DOE's National Nuclear Security Agency (NNSA) asked Pacific Northwest National Laboratory (PNNL) to consider the role of individual scientists in upholding safety and security. The views of scientists were identified as being a critical component of this policy process. Therefore, scientists, managers, and representatives of Institutional Biosafety Committees (IBCs) at the national labs were invited to participate in a brief survey that was designed to:

- Evaluate the function of the 2006 outreach and education seminars that were conducted by the U.S. DOE.

- Assess the opinions of scientists about potential future mechanisms to address dual-use concerns in the life sciences community.

- Gather data on scientists' attitudes toward potential security risks from agricultural, public health, and biomedical research.

- Give scientists a voice in the policy-making process.

In addition, three focus groups were conducted with scientists, managers, and IBC representatives to discuss some of the questions related to education, outreach, and codes of conduct in more detail and gather further input on biosecurity and dual-use awareness at the laboratories. The overall purpose of this process was to identify concerns related to these topics and to gather suggestions for creating an environment where both the scientific enterprise and national security are enhanced.

The information gathered through the survey and focus groups will be instrumental in informing the U.S. position at the Biological Weapons Convention (BWC) Experts' Group meeting in August 2008, as well as moving toward a sustainable mechanism for biosecurity education and awareness. It will also help guide DOE action in developing educational tools that will help promote a laboratory culture of responsibility.

This report presents the results from the web survey. The focus group findings are presented in a separate report. 


\subsection{Methods}

The survey was developed by the PNNL project team in consultation with CPHRE researchers. PNNL programmed the web survey using their proprietary web-survey software. The PNNL Project Director distributed the survey by sending e-mail invitations to individuals who participated in the 2006 training and other points of contact at each of the national laboratories $(\mathrm{N}=202)$. Of these, 173 were delivered and 29 were returned undeliverable. This e-mail introduced the purpose of the survey and invited individuals to participate by clicking on a link. Individuals were also encouraged to forward the survey link to others who might be interested in participating. Several follow-up e-mails were sent to the entire sample encouraging participation. Forty-nine (49) individuals initiated the web survey. Two cases were removed due to incomplete surveys, leaving a final sample of 47 respondents. A copy of the survey instrument used is included in Appendix A.

\subsection{Sample Description}

Survey respondents represented several labs, with the majority (58\%) located in Pacific Northwest, Oak Ridge, and Sandia. Most of the respondents (68\%) have doctorate degrees (or the equivalent). The year in which the highest degree was awarded ranges from 1969 to 2007, with 1985 as the median year. Respondents work or study in a variety of scientific disciplines, including Biodefense (15\%), Biotechnology (13\%), and Molecular Biology (13\%). Senior Research Scientists make up the largest role group (43\%), with others representing Program/Project Managers (19\%), Mid-level Research Scientists (17\%), Laboratory Managers (10\%), and Others (12\%), including Institutional Review Board or Institutional Biosafety Committee Chair or Member, Biological Safety Officer, Research Ops Manager, and Post Doc. A majority of respondents conduct or manage research in the life sciences and contribute to journal articles. Thirty-eight percent (38\%) have also served on an Institutional Biosafety Committee. None of the respondents have served on an Institutional Review Board (IRB).

\subsection{Key Findings}

In this section, we highlight the key findings for each section of the survey. Specific results for each research question are presented in Section 5 (Survey Results).

\subsection{Biosafety Awareness and Experience (Questions 4-10)}

One-half of the respondents consider that they are currently conducting or managing research with dualuse potential, and $57 \%$ have had experience with Select Agents. Only a small percentage (4\%) consider that their work would fall under the 7 categories identified by the NSABB for special review (i.e. experiments "of dual-use concern"). Most respondents (89\%) consider that they are familiar with BWC; however, only $63 \%$ are familiar with the individual provisions for biosafety and biosecurity, and only $64 \%$ are familiar with the BWC introducing the concept of individual responsibility. 


\subsection{Outreach and Education Training (Questions 11-24)}

More than one-half of the respondents (57\%) participated in the 2006 Outreach and Education Training. At least $44 \%$ of the respondents found the trainings to be relatively effective in terms of training materials, venue, and presentation. Training materials were considered to be less than effective by $29 \%$ of the attendees, the presentations were found to be less than effective by $22 \%$ of attendees.

Web-based training is the preferred training type, with $81 \%$ of respondents choosing that option when asked to choose between web-based, classroom training, or reference book for recommended or mandatory training on the BWC. Six percent of participants indicated that no training was necessary.

Few have made changes in research conduct or management in the past 2 years as a result of dual-use research concerns. A small portion of scientists did change the focus of a research project, modify a paper or presentation, or limit conversation and/or collaboration with other scientists. Although most scientists have not made significant modifications in how they undertake research, over $68 \%$ participated in discussions regarding dual-use issues with management, researchers, and IBC participants.

Most scientists indicated training on these subjects should be widespread, and include senior and junior scientists, program, project, and laboratory managers, and IBC/IRB chairs and members.

\subsection{Publication and Journal Review (Questions 26-34)}

While most respondents have reviewed manuscripts for a journal, few (7\%) have reviewed a manuscript that they felt contained knowledge, tools, or techniques that could pose a threat to national security. Although a relatively large proportion did not know whether journals required reviewers to evaluate manuscripts for potential dual-use information or whether the professional science societies of which they are members have codes of conduct for dual-use research. Also, most agree that journals should have guidelines and that professional science societies should have codes of conduct regarding dual-use research.

\subsection{Minimizing Threat to National Security (Questions 38-61)}

The next sections discuss findings for the area of the survey that asked respondents' opinions on possible actions that could be taken to minimize the potential threat to national security that may be posed by knowledge, tools, or techniques from dual-use research.

\subsubsection{Role and Responsibilities of Scientists (Questions 38-42)}

Most believe that scientists taking responsibility for evaluating dual-use potential in their research and assuring institutions of this assessment would help reduce the potential threat to national security. Respondents strongly indicated that principal investigators should conduct an initial evaluation of the dual-use potential of their work; agreement was less strong that scientists should provide formal assurance to their institution that they are assessing their work for dual-use potential.

There is some disagreement among respondents regarding whether scientists should be required to take a Hippocratic-like oath or to obtain certification to conduct dual-use research. Although $28 \%$ of respondents believe that providing greater federal oversight would minimize potential threat, the majority of respondents had no opinion about this option or disagreed. 


\subsubsection{Access to Agents and Equipment (Questions 45-46)}

A majority of respondents (66\%) indicated that requiring licensure of biological equipment would not minimize potential threat to national security, but there was disagreement about whether greater restrictions on agents/toxins would make a difference. Almost one-half $(45 \%)$ agreed that the restrictions would minimize risk, and nearly the same number (43\%) disagreed. This disagreement does not vary by role, laboratory, or year of degree-members within groups disagreed with each other.

\subsubsection{Research Findings (Questions 49-52)}

Actions related to Research Findings received mixed support. One of the consistent findings is that nearly $20 \%$ of respondents neither agreed nor disagreed with the proposed restrictions on research findings. Nearly equal proportions agreed versus disagreed with statements regarding placing restrictions on disclosure through personal communication, alterations prior to publication or presentation, and restrictions on publication of findings. Forty-six percent (46\%) of respondents agreed that classifying research findings would minimize the potential threat to national security compared to $31 \%$ who disagreed.

\subsubsection{Training (Questions 55-57)}

Respondents generally agreed that principal investigators (PIs) providing training for laboratory staff, students, and visiting scientists would minimize potential threat to national security. Having institutions provide mandatory training for scientists regarding dual-use life sciences research also received support, although less strongly than PIs providing recommended training. There was very strong support that training be given to university and college students.

\subsubsection{Review and Funding (Questions 60-61)}

Forty-seven percent (47\%) of respondents agreed that the review of all grant proposals by entities like an IBC prior to submission would minimize risk, while $43 \%$ disagreed. The majority of respondents (62\%) agreed that potential threat would be minimized if funding agencies required grantee applicants to attest that dual-use implications have been considered.

\subsection{Opinions about Bioterrorism and Dual-Use Research (Questions 64-73)}

When asked about the level of existing threat of bioterrorism, respondents indicated that there was an average $57 \%$ chance that an act of bioterrorism would occur "in the world" in the next five years and an average $37 \%$ chance that one would occur in the United States. One-half of the respondents said that there was up to a $25 \%$ chance that dual-use research will facilitate acts of bioterrorism.

Forty-three percent (43\%) of respondents did not agree with the statement that funding agencies would be less likely to fund grant proposals if the proposed research had dual-use potential, and $30 \%$ were neutral or had no opinion. Respondents believe that the most likely ways to obtain potentially sufficient information to deliberately create a harmful biological agent are via scientific journal articles and the internet. There was some disagreement about whether presentations at conferences or meetings or personal communications could provide sufficient information. 


\subsection{Conclusions and Recommendations}

Respondents indicate that they are generally aware of the risks associated with research having dual-use potential. Over half had participated in the PNNL pilot training on the BWC, dual-use risks, and codes of conduct. Additionally, some had become aware of these issues through emerging guidelines or personal reading. Just one-half are currently conducting or managing research with dual-use potential and slightly more have been involved with Select Agents, but most indicated that they are familiar with the Biological Weapons Convention. Many also indicated that they are familiar with the associated provisions and articles.

Although many do not know to what extent scientific journals and professional societies have requirements or codes of conduct related to dual-use potential, most agree that journals and professional societies should have these in place. There was general agreement that training on the BWC, dual-use potential, and codes of conduct by project PIs would help minimize risk. There was agreement, though less strongly, that institutions should provide mandatory training on these topics. There was strong agreement that colleges and universities should offer this training.

The level of threat of bioterrorist acts is considered to be relatively high. However, respondents believe that the chance that an act of bioterrorism would be facilitated by dual-use life sciences research is only about $25 \%$. Of the possible means of communication that could provide sufficient information for an individual with college-level life science training to deliberately create a harmful biological agent, the internet and scientific journals were considered to be the most likely means.

One of the ways in which respondents believe risk to national security could be minimized is through training. Respondents recommended that training that covers scientist obligations under the BWC, dualuse risks of research, and codes of conduct should be provided to nearly all groups, including scientists of all levels, program/project/laboratory managers, and IBC/IRB chairs and members. There was also support for training for research associates and technicians. Most respondents agreed that the potential threat to national security would be minimized if principal investigators trained laboratory staff, students, and visiting professors about dual-use research and if university and college students received education about the potential misuse of life sciences research.

Over one-half of the respondents participated in the 2006 Outreach and Education Training on the Biological Weapons Convention, Dual-Use in the Life Sciences, and Codes of Conduct given by the U.S. Department of Energy. On a scale of 1-5, with 5 being "Very Effective," at least $70 \%$ of respondents rated the training from 3-5 for training materials, venue, and presentation. Of the three aspects of training, respondents rated the training materials least favorable, with $29 \%$ indicating that the training materials were "Not effective." Respondents prefer "web-based" training to "classroom training" or "reference book" training. A combination of training options may be ideal. Some respondents referred to the importance of live discussion with trainers and the usefulness of having reference books in combination with web-based training. A self-paced web-based training with reference handbook and scheduled LiveMeeting or chat session might be an effective combination.

In addition to participating in training discussions regarding dual-use research or codes of conduct, respondents demonstrate awareness of the related issues as a result of new guidelines addressing dual-use research and personal reading or research. Most have not made any changes in the past 2 years in how they conduct or manage research because of concerns that their research may be misused for bioterrorism. Of those who have made changes, some have done so by limiting conversations about their research. 
Scientists' concerns about the dual-use potential of their did not seem to deter them from conducting the research, collaborating, submitting manuscripts, or presenting research. It seems indicated that the value of education is not effected through scientists' changing research topics or publication strategies, but rather, through raising awareness, and better equipping scientists to manage risk.

Respondents believe that scientists should have responsibility for minimizing potential threat to national security by conducting evaluations of dual-use potential of their own research and providing assurance to their institutions or funding agencies that this assessment has been made. Overall, respondents do not think that requiring scientists to take an oath to carry out research responsibly, or requiring researchers to be certified, or providing greater Federal oversight of dual-use research would lead to less risk to national security. Not all believe that providing mandatory training for scientists regarding dual-use life sciences research would minimize risk-24\% indicated a neutral response to this action, and $26 \%$ disagreed.

Putting restrictions on access to biological agents, and on dissemination of research, received mixed support. Most disagree that requiring licensure of certain biological equipment often used in life science research would minimize potential threat to national security, but respondents' opinions vary when evaluating actions involving greater restrictions on access to specific biological agents/toxins or restrictions on publication of findings or disclosure of research details based on dual-use potential. There is some support for classifying research findings on dual-use potential. Comments supplied at the end of the survey indicate that some believe strongly that information with dual-use potential is readily available and that restrictions on the dissemination of information could do more harm by limiting research advances.

The processes of funding research and disseminating research details and findings are considered to be areas worthy of potentially useful restrictions by some, but not by all. There is disagreement about whether having an individual or board (like an IBC) review all life sciences grant proposals with dual-use potential prior to submission will minimize threat to national security. Similarly, there is variable support for actions such as placing restrictions on disclosure through personal communication or publication and altering methods or findings before publication or presentation. It is not clear whether certain groups of respondents were more likely to agree or disagree with these statements. We did find that a larger percentage of 2006 Outreach and Education trainees versus non-trainees agreed that the action "Placing restrictions on disclosure of details about the research or its findings through personal communication" would minimize threat but it is not clear that the difference is significant.

Education about the risks associated with life sciences research with dual-use potential is considered a valuable tool in protecting against acts of bioterrorism. The respondents in this sample support the idea of providing training to scientists, technicians, managers, IBC/IRB members, and students in order to increase awareness about potential security risks associated with life sciences research. Those who participated in the 2006 Outreach and Education Training by the Department of Energy found it to be relatively effective and most would recommend a primarily web-based training to cover topics related to the Biological Weapons Convention, codes of conduct, and dual-use concerns.

Respondents seem to favor self-imposed restrictions and research evaluation as opposed to mandated training/certification, additional board review processes, or government restrictions on access to equipment or oversight of dual-use research. One issue raised in several comments at the end of the survey indicated concern that any restriction or regulation or mandatory guidelines would be "untargeted" and impact life science research that does not have significant dual-use concerns. They welcome the development of publication guidelines and scientific society codes of conduct regarding dual-use research. However, through comments, scientists also raised concern that any attempt to reduce the risk of bioterrorism through guidelines or regulations would hamper research and limit the dissemination of new 
knowledge. Additional comments indicated that education and personal accountability are critical to successful biosecurity. 



\section{Appendix A}

\section{Survey Instrument}


Welcome!

Rapid developments in biotechnology and the life sciences bring significant benefits, but also create new security challenges. In recent years, members of the scientific and security policy communities have raised concerns about the potential for misuse of knowledge, tools and techniques for purposes of bioterrorism. Such research is sometimes called "dual-use" research because, although the research is intended for beneficial purposes only, it could be misapplied. The role of scientists, institutions, scientific societies, and the government is critical in fostering an environment that enhances both the scientific enterprise and national security.

In 2004, the U.S. government established the National Science Advisory Board on Biosecurity (NSABB) under the auspices of the National Institutes of Health to contemplate the possibility and impact of greater oversight for life sciences research to prevent or mitigate deliberate misuse. Similarly, the US Department of Energy (DOE) is considering how to respond to emerging issues of concern related to dual-use. Other Federal agencies are planning to issue further guidelines and considering additional policies regarding responsible scientific research.

Your views are critical in this policy process. It is very important for the government to be aware of and informed by the views of scientists - to hear your concerns and also your suggestions for creating an environment where both the scientific enterprise and national security are enhanced.

The DOE's National Nuclear Security Agency (NNSA) has asked Pacific Northwest National Laboratory (PNNL) to consider the role of individual scientists in upholding safety and security. Therefore, we invite you to participate in this brief survey, which is designed to:

- evaluate the function of the 2006 outreach and education seminars that were conducted by the U.S. Department of Energy,

- assess the opinions of scientists about potential future mechanisms to address dual-use concerns in the life sciences community,

- gather data on scientists' attitudes toward potential security risks from agricultural, public health, and biomedical research, and

- give scientists a voice in the policy making process,

The survey will take approximately 20 minutes to complete. While the results will be summarized in aggregate, it is possible that combinations of responses to some of the questions in the survey could allow an individual respondent to be identified. Please note that you may skip any question you do not wish to answer. Aggregate survey results will be shared with policy makers and the scientific community.

Thank you for your vital contribution to this important policy process. 


\section{Questions}

Laboratory:

Title:

\section{GENERAL QUESTIONS}

1. Please note which of the following activities your work scope includes. (Please check all that apply):

Conducting research in the life sciences

Managing research in the life sciences

Serving on an Institutional Biosafety Committee (IBC)

Serving on an Institutional Review Board (IRB)

Contributing to journal articles

2. Do you consider any of the research you currently conduct or manage as having dual-use potential?

Yes

No

3. Do you now, or have you ever, worked with or managed research using Select Agents?

Yes

No

Don't know

The National Science Advisory Board for Biosecurity (NSABB) has identified a subset of life sciences research that they believe may be worthwhile but may also need special review. Such research includes experiments designed to:

(1) enhance the harmful consequences of a biological agent or toxin;

(2) disrupt immunity or the effectiveness of an immunization without clinical and/or agricultural justification;

(3) confer to a biological agent or toxin, resistance to clinically and/or agriculturally useful prophylactic or therapeutic interventions against that agent or toxin, or facilitate their ability to evade detection methodologies;

(4) increase the stability, transmissibility, or the ability to disseminate a biological agent or toxin;

(5) alter the host range or tropism of a biological agent or toxin;

(6) enhance the susceptibility of a host population; and

(7) generate a novel pathogenic agent or toxin, or reconstitute an eradicated or extinct biological agent. 
4. Are you currently conducting or managing research which includes any of these seven types of experiments?

$\square \quad$ Yes
$\square \quad$ No
$\square \quad$ Don't Know

5. Are you familiar with the Biological Weapons Convention (BWC)?

$$
\begin{aligned}
& \text { Yes } \rightarrow \text { (Continue to Q5a) } \\
& \text { No } \rightarrow(\text { Skip to Q6) } \\
& \text { Don't Know } \rightarrow \text { (Skip to Q6) }
\end{aligned}
$$

a. Are you familiar with the provisions for biosafety and biosecurity as discussed in its individual Articles?

$$
\begin{array}{ll}
\square \quad \text { Yes } \\
\square \quad \text { No } \\
\square \quad \text { Don't Know }
\end{array}
$$

6. Are you aware that Article IV of the BWC introduces the concept of individual responsibility for upholding and promoting the nonproliferation obligations (assumed by the U.S. as a State Party to the BWC)?

$$
\begin{aligned}
& \text { Yes } \\
& \text { No } \\
& \text { Don't Know }
\end{aligned}
$$

\section{QUESTIONS RELATED TO 2006 OUTREACH AND EDUCATION TRAINING}

7. Did you participate in the 2006 Outreach and Education Training on the Biological Weapons Convention, Dual-Use in the Life Sciences, and Codes of Conduct?

Yes

No $\rightarrow$ (Skip to Question 9) 
8. How effective were the following aspects of the training in conveying information on the BWC, codes of conduct, and dual-use and biosecurity concerns?

Not effective at all

\begin{tabular}{|l|c|c|c|c|c|}
\hline Training materials & 1 & 2 & 3 & 4 & 5 \\
\hline Venue & 1 & 2 & 3 & 4 & 5 \\
\hline Presentation & 1 & 2 & 3 & 4 & 5 \\
\hline
\end{tabular}

9. If a recommended or mandatory training on the BWC and dual-use research were offered with a choice of web-based training, on-site classroom training, or as a reference handbook, which would you choose?
Web-based
Classroom Training
Reference Book
Other (Please Specify

10. Have you made any changes in the past 2 years in how you conduct or manage research because of concerns that knowledge, tools or techniques from your research might be deliberately misused to facilitate bioterrorism?

\begin{tabular}{|l|r|r|}
\hline \multicolumn{1}{l}{ Y } & Nos & Nocided against conducting a specific research project/experiment \\
I decided to shift my research away from an area altogether & $\square$ & $\square$ \\
\hline I decided against seeking funding for a proposed research project & $\square$ & $\square$ \\
\hline I decided against collaborating with particular scientists, postdocs, students, etc. & $\square$ & $\square$ \\
\hline I limited my conversations about my research & $\square$ & $\square$ \\
\hline I decided against submitting a manuscript to a journal & $\square$ & $\square$ \\
\hline I modified a manuscript & $\square$ & $\square$ \\
\hline I decided against presenting research at a conference & $\square$ & $\square$ \\
\hline I modified a conference presentation & $\square$ & $\square$ \\
\hline
\end{tabular}

(If no to all of the items in Question 10, skip to question 12) 
11. What contributed to this change in how you conduct or manage research? (Please check all that apply)

Training conducted by PNNL

Training provided by another laboratory or organization (If yes, please specify

Other related training or education (If yes, please specify

New or emerging guidelines addressing dual-use research

Personal reading or research

Other (Please Specify

12. Have you participated in any discussions regarding dual-use research or codes of conduct with management, researcher or Institutional Biosafety Committee (IBC) participants?

Yes

No $\rightarrow$ (Skip to Question 14)

13. If yes, were these discussions a result of any or all of the following?

\begin{tabular}{|l|r|r|}
\multicolumn{2}{c}{ Yes } & No \\
\hline Training conducted by PNNL & $\square$ & $\square$ \\
\hline Training conducted by another laboratory or organization & $\square$ & $\square$ \\
\hline Other related training or organization & $\square$ & $\square$ \\
\hline New or emerging guidelines addressing dual-use research & $\square$ & $\square$ \\
\hline Personal reading or research & $\square$ & $\square$ \\
\hline
\end{tabular}

14. Who should participate in training that covers scientist obligations under the BWC, dual-use risks of research, and codes of conduct? (Please check all that apply)
Senior Reseach Scientists
Mid-level Research Scientists
Junior Scientists
Program/Project Managers
Laboratory Managers
IBC/IRB chairs and members
Research associates/technicians
Other (Please Specify
There is no need for such training 


\section{QUESTIONS RELATED TO PUBLICATION AND JOURNAL REVIEW}

15. Have you ever reviewed a manuscript for a journal?

Yes

No $\rightarrow$ (skip to Q18)

16. Have you ever felt that a manuscript you were reviewing contained knowledge, tools or techniques that could pose a threat to national security?

$$
\begin{aligned}
& \text { Yes } \\
& \text { No } \rightarrow \text { (skip to Q18) }
\end{aligned}
$$

17. Have you ever contacted an editor to raise this concern?

$$
\begin{aligned}
& \text { Yes } \\
& \text { No }
\end{aligned}
$$

18. How many of the journal(s) in your field require reviewers to evaluate whether manuscripts include knowledge, tools and techniques with dual-use potential?
All of the journals
Most of the journals
Some of the journals
A few of the journals
None of the journals
Don't know

Please indicate your opinion about the following two statements:

\begin{tabular}{|l|c|c|c|c|c|}
\cline { 2 - 5 } \multicolumn{1}{c|}{} & $\begin{array}{c}\text { Strongly } \\
\text { Agree }\end{array}$ & Agree & $\begin{array}{c}\text { Neutral/ } \\
\text { No Opinion }\end{array}$ & Disagree & $\begin{array}{c}\text { Strongly } \\
\text { Disagree }\end{array}$ \\
\hline $\begin{array}{l}\text { 19. Scientific journals should have guidelines } \\
\text { regarding publication of dual-use research. }\end{array}$ & $\square$ & $\square$ & $\square$ & $\square$ & $\square$ \\
\hline $\begin{array}{l}\text { 20. Professional science societies should have } \\
\text { codes for the responsible conduct of dual-use } \\
\text { life sciences research. }\end{array}$ & $\square$ & $\square$ & $\square$ & $\square$ & $\square$ \\
\hline
\end{tabular}


21. Are you a member of any professional science societies that have codes of responsible conduct for dual-use research?

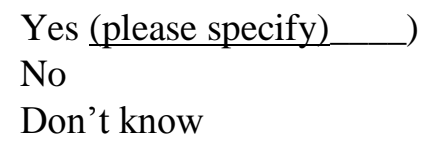

No

Don't know

Next we would like to ask your opinion on possible actions that could be taken to minimize the potential threat to national security that may be posed by knowledge, tools, or techniques from dual-use research.

For each item under Role and Responsibilities of Scientists, please indicate whether you think this action would minimize the potential threat to national security.

\begin{tabular}{|c|c|c|c|c|c|}
\hline 22. Role and Responsibilities of Scientists & $\begin{array}{c}\text { Strongly } \\
\text { Agree }\end{array}$ & Agree & $\begin{array}{c}\text { Neutral/ } \\
\text { No Opinion }\end{array}$ & Disagree & $\begin{array}{l}\text { Strongly } \\
\text { Disagree }\end{array}$ \\
\hline $\begin{array}{l}\text { a. Principal investigators conducting an initial } \\
\text { evaluation of the dual-use potential of their } \\
\text { life sciences research. }\end{array}$ & $\square$ & $\square$ & $\square$ & $\square$ & $\square$ \\
\hline $\begin{array}{l}\text { b. Scientists providing formal assurance to } \\
\text { their institution that they are assessing their } \\
\text { work for dual-use potential (e.g. such as } \\
\text { following dual-use recommendations or } \\
\text { guidelines) }\end{array}$ & $\square$ & $\square$ & $\square$ & $\square$ & $\square$ \\
\hline $\begin{array}{l}\text { c. Requiring scientists conducting or managing } \\
\text { research to take an oath, similar to } \\
\text { medicine's Hippocratic Oath, to carry out } \\
\text { research responsibly and guard against } \\
\text { deliberate misuse of the knowledge, tools or } \\
\text { techniques of dual-use research }\end{array}$ & $\square$ & $\square$ & $\square$ & $\square$ & $\square$ \\
\hline $\begin{array}{l}\text { d. Requiring certification for researchers } \\
\text { conducting some dual-use research. }\end{array}$ & $\square$ & $\square$ & $\square$ & $\square$ & $\square$ \\
\hline $\begin{array}{l}\text { e. Providing greater federal oversight of dual- } \\
\text { use research. }\end{array}$ & $\square$ & $\square$ & $\square$ & $\square$ & $\square$ \\
\hline
\end{tabular}


For each item under Access to Agents and Equipment, please indicate whether you think this action would minimize the potential threat to national security.

\begin{tabular}{|c|c|c|c|c|c|}
\hline 23. Access to Agents and Equipment & $\begin{array}{l}\text { Strongly } \\
\text { Agree }\end{array}$ & Agree & $\begin{array}{c}\text { Neutral/ } \\
\text { No Opinion }\end{array}$ & Disagree & $\begin{array}{l}\text { Strongly } \\
\text { Disagree }\end{array}$ \\
\hline $\begin{array}{l}\text { a. Placing greater restrictions on access to } \\
\text { specific biological agents or toxins. }\end{array}$ & $\square$ & $\square$ & $\square$ & $\square$ & $\square$ \\
\hline $\begin{array}{l}\text { b. Requiring licensure of certain biological } \\
\text { equipment that is commonly used in life } \\
\text { science research. }\end{array}$ & $\square$ & $\square$ & $\square$ & $\square$ & $\square$ \\
\hline
\end{tabular}

For each item under Research Findings, please indicate whether you think this action would minimize the potential threat to national security.

\begin{tabular}{|c|c|c|c|c|c|}
\hline 24. Research Findings & $\begin{array}{c}\text { Strongly } \\
\text { Agree }\end{array}$ & Agree & $\begin{array}{c}\text { Neutral/ } \\
\text { No Opinion }\end{array}$ & Disagree & $\begin{array}{l}\text { Strongly } \\
\text { Disagree }\end{array}$ \\
\hline $\begin{array}{l}\text { a. Placing restrictions on disclosure of details } \\
\text { about the research or its findings through } \\
\text { personal communication. }\end{array}$ & $\square$ & $\square$ & $\square$ & $\square$ & $\square$ \\
\hline $\begin{array}{l}\text { b. Altering or removing certain experimental } \\
\text { methods or findings prior to publication or } \\
\text { presentation. }\end{array}$ & $\square$ & $\square$ & $\square$ & $\square$ & $\square$ \\
\hline $\begin{array}{l}\text { c. Placing restrictions on publication of } \\
\text { findings based on dual-use potential. }\end{array}$ & $\square$ & $\square$ & $\square$ & $\square$ & $\square$ \\
\hline $\begin{array}{l}\text { d. Classifying research findings on dual-use } \\
\text { potential. }\end{array}$ & $\square$ & $\square$ & $\square$ & $\square$ & $\square$ \\
\hline
\end{tabular}

For each item under Training, please indicate whether you think this action would minimize the potential threat to national security.

\begin{tabular}{|c|c|c|c|c|c|}
\hline 25. Training & $\begin{array}{c}\text { Strongly } \\
\text { Agree }\end{array}$ & Agree & $\begin{array}{c}\text { Neutral/ } \\
\text { No Opinion }\end{array}$ & Disagree & $\begin{array}{l}\text { Strongly } \\
\text { Disagree }\end{array}$ \\
\hline $\begin{array}{l}\text { a. Principal investigators providing training to } \\
\text { lab staff, students and visiting scientists } \\
\text { about dual-use research including policies } \\
\text { and practices to minimize the potential for } \\
\text { misuse of information from their research. }\end{array}$ & $\square$ & $\square$ & $\square$ & $\square$ & $\square$ \\
\hline $\begin{array}{l}\text { b. University and college students receiving } \\
\text { educational lectures and materials on dual- } \\
\text { use life sciences research including the } \\
\text { potential that knowledge, tools and } \\
\text { techniques of such research that could pose } \\
\text { a threat to national security. }\end{array}$ & $\square$ & $\square$ & $\square$ & $\square$ & $\square$ \\
\hline $\begin{array}{l}\text { c. Institutions providing mandatory training for } \\
\text { scientists regarding dual-use life sciences } \\
\text { research. }\end{array}$ & $\square$ & $\square$ & $\square$ & $\square$ & $\square$ \\
\hline
\end{tabular}


For each item under Review and Funding, please indicate whether you think this action would minimize the potential threat to national security.

\begin{tabular}{|c|c|c|c|c|c|}
\hline 26. Review and Funding & $\begin{array}{c}\text { Strongly } \\
\text { Agree }\end{array}$ & Agree & $\begin{array}{c}\text { Neutral/ } \\
\text { No Opinion }\end{array}$ & Disagree & $\begin{array}{l}\text { Strongly } \\
\text { Disagree }\end{array}$ \\
\hline $\begin{array}{l}\text { a. Reviewing all grant proposals for life } \\
\text { sciences research with dual-use potential by } \\
\text { an appropriate individual or board (such as } \\
\text { an IBC) at a researcher's institution prior to } \\
\text { submission for funding. }\end{array}$ & $\square$ & $\square$ & $\square$ & $\square$ & $\square$ \\
\hline $\begin{array}{l}\text { b. Funding agencies requiring grantees to attest } \\
\text { on grant applications that they have } \\
\text { considered dual-use implications of their } \\
\text { proposed research. }\end{array}$ & $\square$ & $\square$ & $\square$ & $\square$ & $\square$ \\
\hline
\end{tabular}

\section{Next we are interested in your opinions about bioterrorism and dual-use research.}

27. Please indicate your opinion about the following statement: Funding agencies would be less likely to fund grant proposals if the proposed research had dual-use potential.

$\begin{array}{llll}\text { Strongly agree } & \text { Agree } & \text { Neutral/No opinion } & \text { Disagree }\end{array}$

28. In your opinion, what is the percent chance (ranging from $0 \%$ chance to $100 \%$ chance) that an act of bioterrorism will occur somewhere in the next five years?

In the world:

In the United States:

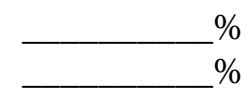

29. In your opinion, what is the percent chance (ranging from $0 \%$ chance to $100 \%$ chance) that knowledge, tools or techniques from dual-use life sciences research will facilitate an act of bioterrorism somewhere in the world in the next five years? 
30. In your opinion, do the following means of communication have the ability to provide sufficient information for an individual with college level life science training to deliberately create a harmful biological agent?

Scientific journal articles

Yes No Don't Know

Presentations at scientific conferences or meetings

Personal communications (e.g., e-mail, phone calls)

Internet

And finally, please give us a little information about yourself:

31. What is the highest educational degree you have been awarded?

Bachelor's degree or equivalent (e.g., BS, BA, AB)

Master's degree or equivalent (e.g., MS, MA, MBA, etc.)

Doctorate or equivalent (e.g., $\mathrm{PhD}, \mathrm{DSc}, \mathrm{EdD}$, etc.)

Other professional degree (e.g., JD, LLB, MD, DDS, DVM, etc.)

Joint doctorate and professional degree (e.g. Ph.D. and MD)

Other

32. In what year was your highest educational degree awarded?

(YYYY)

33. Which scientific discipline do you consider your primary area of work or study? (If currently unemployed or retired, please select the discipline that most closely matches your last occupation.)

\author{
Agricultural Science \\ Biochemistry \\ Biodefense \\ Biomedical Engineering \\ Biotechnology \\ Botany \\ Cell Biology \\ Ecology \\ Endocrinology/Physiology \\ Genetics \\ Geology/Soil Sciences/Geography \\ Immunology \\ Marine Biology \\ Medicine \\ Microbiology
}


$\square \quad$ Molecular Biology

$\square \quad$ Neuroscience

$\square$ Pharmacology

$\square$ Zoology

$\square$ Other:

34. Which best describes your current role?

$\square$ Senior Research Scientist

$\square$ Mid-level Research Scientist

$\square$ Junior Scientist

$\square$ Program/Project Manager

$\square \quad$ Laboratory Manager

$\square$ Research associate/technician

$\square$ Other (Please Specify

35. Do you have any additional comments regarding regulation and oversight of dual-use research you would like federal policy makers to consider?

\section{[TEXT FIELD]}


Thank you very much for taking the time to complete this survey!

It is very important for the U.S. government to be aware of and informed by the views of the nation's scientists - hearing your concerns and your suggestions helps create an environment where both the scientific enterprise and national security are enhanced.

Thank you again. 

Appendix B

Survey Answers 
This section presents the survey results in greater detail. Summaries of results are given preceding each question or set of questions. Sample sizes are provided in parentheses.

\section{B.1 Laboratory}

Respondents were asked to type in the name of the laboratory where they worked. Table 1 shows the distribution of responses. The majority of respondents (58\%) are located in the Oak Ridge, Pacific Northwest, and Sandia labs, with most located in the Pacific Northwest (28\%).

\begin{tabular}{|c|c|}
\hline Question 1: Laboratory & $\%$ Respondents (N \\
\hline Argonne & $4 \%$ \\
\hline Brookhaven & $9 \%$ \\
\hline Idaho & $6 \%$ \\
\hline Lawrence Berkeley & $6 \%$ \\
\hline Los Alamos & $9 \%$ \\
\hline National Renewable Energy & $4 \%$ \\
\hline Oak Ridge & $15 \%$ \\
\hline Pacific Northwest & $28 \% \quad(13)$ \\
\hline Sandia & $15 \% \quad(7)$ \\
\hline Missing & $4 \%$ \\
\hline Total & $100 \% \quad(47)$ \\
\hline
\end{tabular}

\section{B.2 Biosafety Awareness and Experience (Questions 4-10)}

In the General Questions section of the survey, respondents were asked about experience and awareness of issues related to biosecurity.

Activities in scope of work. For the question regarding scope of work, the respondents were asked to check all that applied. Over $60 \%$ of respondents conduct or manage research in the life sciences and contribute to journal articles. None serve on an Institutional Review Board, but nearly $40 \%$ have served on an Institutional Biosafety Committee.

\begin{tabular}{|lrc|}
\hline Question 3: Activities included in work scope & $\%$ Respondents (N) \\
Conducting research in the life sciences & $66 \%$ & $(31)$ \\
Managing research in the life sciences & $60 \%$ & $(28)$ \\
Serving on an Institutional Biosafety Committee (IBC) & $38 \%$ & $(18)$ \\
Serving on an Institutional Review Board (IRB) & $0 \%$ & $(0)$ \\
Contributing to journal articles & $62 \%$ & $(29)$ \\
\hline
\end{tabular}

Research with dual-use potential. One-half of the respondents currently conduct or manage research that has dual-use potential. 


\begin{tabular}{|lrr|r|}
\hline $\begin{array}{l}\text { Question 4: Currently conduct or manage research with } \\
\text { dual-use potential }\end{array}$ & \multicolumn{3}{c|}{ \% Respondents (N) } \\
\hline Yes & $50 \%$ & $(23)$ \\
No & $50 \%$ & $(23)$ \\
\hline & Total & $\mathbf{1 0 0 \%}$ & $(\mathbf{4 6})$ \\
\hline
\end{tabular}

Experience with select agents. A majority of respondents (57\%) have ever worked with or managed research using Select Agents.

\begin{tabular}{|c|c|}
\hline $\begin{array}{l}\text { Question 5: Ever worked or managed research using } \\
\text { Select Agents }\end{array}$ & \% Respondents (N) \\
\hline $\begin{array}{l}\text { Yes } \\
\text { No }\end{array}$ & $\begin{array}{ll}57 \% & (26) \\
43 \% & (20)\end{array}$ \\
\hline Total & $100 \% \quad(46)$ \\
\hline
\end{tabular}

Research needing special review. In preparation for Question 7, respondents were presented with a list of seven types of life sciences research that may require special review. This list is shown in the box below.

\section{Preface to Question 7: Involved in Research that Potentially Needs Special Review}

The National Science Advisory Board for Biosecurity (NSABB) has identified a subset of life sciences research that they believe may be worthwhile but may also need special review. Such research includes experiments designed to:

(1) enhance the harmful consequences of a biological agent or toxin;

(2) disrupt immunity or the effectiveness of an immunization without clinical and/or agricultural justification;

(3) confer to a biological agent or toxin, resistance to clinically and/or agriculturally useful prophylactic or therapeutic interventions against that agent or toxin, or facilitate their ability to evade detection methodologies;

(4) increase the stability, transmissibility, or the ability to disseminate a biological agent or toxin;

(5) alter the host range or tropism of a biological agent or toxin;

(6) enhance the susceptibility of a host population; and

(7) generate a novel pathogenic agent or toxin, or reconstitute an eradicated or extinct biological agent.

Most of the respondents are not currently conducting or managing research that includes the types of experiments that potentially need special review.

\begin{tabular}{|c|c|}
\hline $\begin{array}{l}\text { Question 7: Conducting or managing research that might } \\
\text { need special review }\end{array}$ & \% Respondents (N) \\
\hline Yes & $4 \%$ \\
\hline No & $89 \% \quad(42)$ \\
\hline Don't Know & $6 \% \quad(3)$ \\
\hline Total & $100 \% \quad(47)$ \\
\hline
\end{tabular}


Familiarity with biological weapons convention. Questions 8-10 (Tables 7-9) assess the respondents' familiarity with the Biological Weapons Convention and Articles. Nearly all of the respondents are familiar with the BWC (89\%) but are less familiar with the provisions for biosafety and biosecurity (63\%) or with Article IV of the BWC that introduces the concept of individual responsibility for upholding and promoting the nonproliferation obligations (64\%).

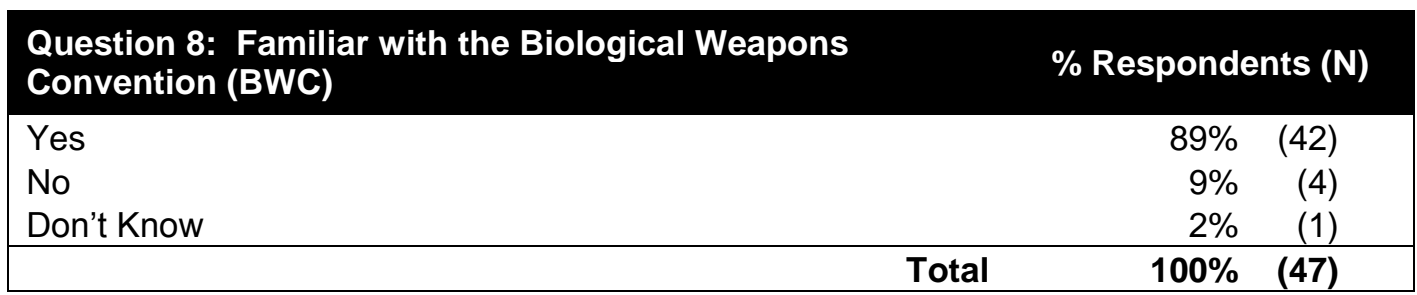

\begin{tabular}{|c|c|}
\hline $\begin{array}{l}\text { Question 9: Familiar with Provisions for Biosafety and } \\
\text { Biosecurity }\end{array}$ & \% Respondents (N) \\
\hline Yes & $63 \% \quad(26)$ \\
\hline No & $27 \%$ \\
\hline Don't Know & $10 \% \quad(4)$ \\
\hline Total & $100 \% \quad(41)$ \\
\hline
\end{tabular}

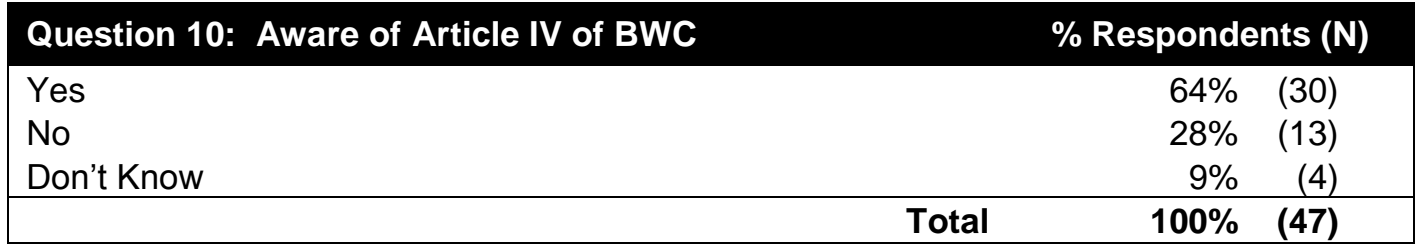

\section{B.3 2006 Outreach and Education Training (Questions 11-24)}

This section of the survey contains questions regarding participation in and evaluation of the 2006 Outreach and Education Training as well as how the respondents' behavior has been affected by training and education.

Training participation. More than one-half of the respondents (57\%) participated in the 2006 Outreach and Education Training on the Biological Weapons Convention, Dual-Use in the Life Sciences, and Codes of Conduct.

\begin{tabular}{|lrr|r|}
\hline $\begin{array}{l}\text { Question 11: Participated in } 2006 \text { Outreach and Education } \\
\text { Training }\end{array}$ & \multicolumn{3}{c|}{ \% Respondents (N) } \\
\hline Yes & $57 \%$ & $(27)$ \\
No & $43 \%$ & $(20)$ \\
\hline & Total & $\mathbf{1 0 0 \%}$ & $(\mathbf{4 7})$ \\
\hline
\end{tabular}

Training effectiveness. In Questions 13-15, respondents who attended the 2006 Outreach and Education Training were asked to rate the training in terms of conveying information on the BWC, codes of conduct, and dual-use and biosecurity concerns. The scale ranged from 1, indicating "Not effective at all," to 5, indicating "Very effective." More of the respondents rated Training Materials, Venue, and Presentation as effective ( 4 or 5) versus not effective ( 1 or 2 ) and nearly $20 \%$ found the Venue and Presentation to be "Very effective." 


\begin{tabular}{|c|c|c|c|c|c|c|}
\hline & $\begin{array}{c}\text { Not } \\
\text { effective at } \\
\text { all } \\
1 \\
\end{array}$ & 2 & 3 & 4 & $\begin{array}{c}\begin{array}{c}\text { Very } \\
\text { Effective }\end{array} \\
5 \\
\end{array}$ & Total \\
\hline 13. Training Materials & $7 \%(2)$ & $22 \%(6)$ & $26 \%(7)$ & $37 \%(10)$ & $7 \% \quad(2)$ & $100 \%(27)$ \\
\hline 14. Venue & $4 \%(1)$ & $11 \%(3)$ & $41 \%(11)$ & $26 \%(7)$ & $19 \%(5)$ & $100 \%(27)$ \\
\hline 15. Presentation & $7 \%(2)$ & $15 \%(4)$ & $30 \%(8)$ & $30 \%(8)$ & $19 \%(5)$ & $100 \%(27)$ \\
\hline
\end{tabular}

Preferred type of training. If a recommended or mandatory training on the BWC and dual-use research were offered, the preferred type of training would be web-based (81\%).

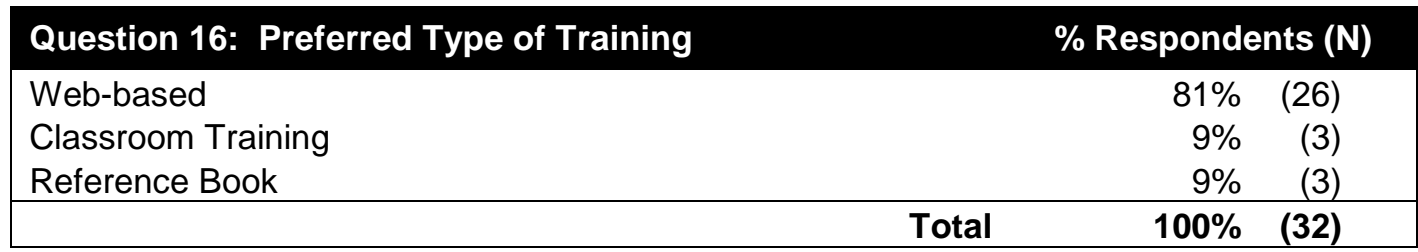

Changes in research behavior due to bioterrorism concerns. Questions 18 and 19 (Tables 14 and 15) elicit information about whether respondents have made any changes in the past 2 years in how they conduct or manage research because of concerns that knowledge, tools, or techniques from their research might be deliberately misused to facilitate bioterrorism. Most of the respondents (77\%) have made no changes. The types of changes that have been made are mainly related to modifications in how information is disseminated (Questions 18-5, 18-7, 18-9) rather than the avoidance of providing information, collaborating, or conducting particular research.

\begin{tabular}{|lcc|}
\hline Question 18: Changes in Research Behavior Due to & \multicolumn{2}{c|}{ \% Yes (N=47) } \\
Bioterrorism Concerns & $4 \%$ & $(2)$ \\
$\begin{array}{l}\text { 18-1. I decided against conducting a specific research } \\
\text { project/experiment }\end{array}$ & $4 \%$ & $(2)$ \\
18-2. I decided to shift my research away from an area altogether & $2 \%$ & $(1)$ \\
$\begin{array}{l}\text { 18-3. I decided against seeking funding for a proposed research } \\
\text { project }\end{array}$ & $2 \%$ & $(1)$ \\
18-4. I decided against collaborating with particular scientists, & & \\
postdocs, students, etc. & $17 \%$ & $(8)$ \\
18-5. I limited my conversations about my research & $2 \%$ & $(1)$ \\
18-6. I decided against submitting a manuscript to a journal & $9 \%$ & $(4)$ \\
18-7. I modified a manuscript & $2 \%$ & $(1)$ \\
18-8. I decided against presenting research at a conference & $11 \%$ & $(5)$ \\
18-9. I modified a conference presentation & $77 \%$ & $(36)$ \\
18-10 No change ("no" to 18-1 through 18-9) & & \\
\hline
\end{tabular}

In Question 19, the 11 respondents who changed their research behavior in the past 2 years due to bioterrorism concerns typed in the sources of the changes. 


\begin{tabular}{ll} 
Question 19: Sources of Changes in Research Behavior Due to & N \\
Bioterrorism Concerns & 3 \\
Training conducted by PNNL & 0 \\
Training provided by another laboratory or organization & 1 \\
Other related training or education: & 3 \\
New or emerging guidelines addressing dual-use research & 3 \\
Personal reading or research & 1 \\
Interaction with PNNL personnel familiar with national security issues & 1 \\
General Security Training and Managing DHS projects & 1 \\
ASM biodefense conference 2007 & 1 \\
ADC & 1 \\
OPSEC & 1 \\
Client confidentiality & 1 \\
Discussion of issues as part of IBC membership & 1 \\
NSABB request to review guidelines, journal review policies for editors and & 1 \\
BNiewers & 1 \\
\hline
\end{tabular}

Discussions about dual-use research and codes of conduct. Questions 22 and 23 refer to discussions about dual-use research and codes of conduct. Most of the respondents (68\%) have participated in discussions regarding dual-use research or codes of conduct with management, researcher, or IBC participants. The discussions were largely a result of "New or emerging guidelines addressing dual-use research" and "Personal reading or research," with training also being an inspiration for discussions.

\begin{tabular}{|lrr|}
\hline Question 22: Participated in Discussions Regarding Dual- & \multicolumn{2}{c|}{$\%$ Respondents (N) } \\
Use Research or Codes of Conduct & $68 \%$ & $(32)$ \\
\hline Yes & $32 \%$ & $(15)$ \\
\hline No & $100 \%$ & $(47)$ \\
\hline Total & & \\
\hline
\end{tabular}

\begin{tabular}{|lrr|}
\hline $\begin{array}{l}\text { Question 23: Sources of Discussions Regarding Dual-Use } \\
\text { Research or Codes of Conduct }\end{array}$ & $\%$ Yes (N=32) \\
\hline 23-1. Training conducted by PNNL & $31 \%$ & $(10)$ \\
23-2. Training conducted by another laboratory or organization & $0 \%$ & $(0)$ \\
23-3. Other related training or organization & $16 \%$ & $(5)$ \\
23-4. New or emerging guidelines addressing dual-use research & $66 \%$ & $(21)$ \\
23-5. Personal reading or research & $66 \%$ & $(21)$ \\
\hline
\end{tabular}

Recommended participants for training. Respondents were asked to check all groups that they believed should participate in training that covers scientist obligations under the BWC, dual-use risks of research, and codes of conduct. Training is recommended for most groups, with only $6 \%$ indicating that there is no need for training of this type. 


\begin{tabular}{lrr|}
$\begin{array}{l}\text { Question 24: Recommended Participants for Scientist } \\
\text { Obligations Training }\end{array}$ & $\%$ Yes (N) \\
\hline 24-1. Senior Research Scientists & $83 \%$ & $(39)$ \\
24-2. Mid-level Research Scientists & $68 \%$ & $(32)$ \\
24-3. Junior Scientists & $60 \%$ & $(28)$ \\
24-4. Program/Project Managers & $79 \%$ & $(37)$ \\
24-5. Laboratory Managers & $68 \%$ & $(32)$ \\
24-6. IBC/IRB chairs and members & $76 \%$ & $(35)$ \\
24-7. Research associates/technicians & $36 \%$ & $(17)$ \\
24-8. Other: & $13 \%$ & $(7)$ \\
$\quad$ Scientists at all levels who actually do or manage potential & & \\
$\quad$ dual use research & & \\
$\quad$ Security Staff, Export Control Staff & & \\
$\quad$ A graded approach with an awareness level for some and & & \\
$\quad$ additional info for responsible mgrs & & \\
$\quad$ OS\&H and facilities support; others as interested & & \\
Select Agent officials & & \\
CDC or Gov't offices funding the research & & \\
24-9.There is no need for such training & & \\
\hline
\end{tabular}

\section{B.4 Publication and Journal Review (Questions 26-34)}

The next section of the survey focuses on experiences with journal manuscripts and on opinions about the roles of journals and professional science societies in the context of the potential of dual-use research.

Scientific journal experiences. In Questions 26-29, respondents were asked about their experiences reviewing manuscripts and their awareness of whether journals require reviewers to evaluate manuscripts for knowledge, tools, and techniques with dual-use potential. Most of the respondents have reviewed manuscripts for journals (87\%). Of those who have reviewed manuscripts, only $3(7 \%)$ have ever felt that a manuscript they were reviewing contained knowledge, tools, or techniques that could pose a threat to national security, and none of those individuals contacted an editor to raise this concern.

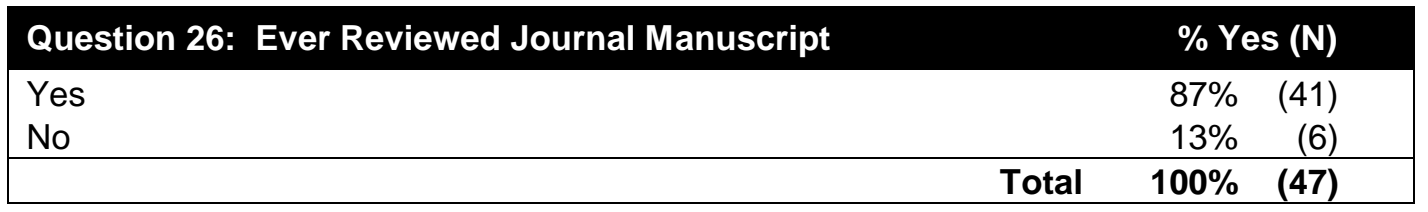

\begin{tabular}{|lrr|r|}
\hline Question 27: Reviewed Manuscript Containing Potential Dual- & \multicolumn{3}{c|}{$\%$ Yes (N) } \\
Use Information & & $7 \%$ & $(3)$ \\
\hline Yes & & $93 \%$ & $(38)$ \\
\hline No & Total & $\mathbf{1 0 0} \%$ & $(\mathbf{4 1})$ \\
\hline
\end{tabular}




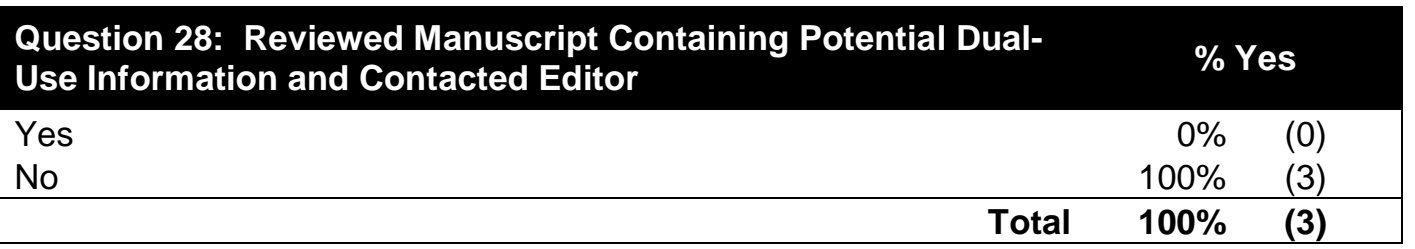

There is variation in respondents' awareness of whether journals require reviewers to evaluate manuscripts for knowledge, tools, and techniques with dual-use potential. Almost one-half of the respondents $(43 \%)$ did not know if this was the case.

\begin{tabular}{|c|c|}
\hline $\begin{array}{l}\text { Question 29: Proportion of Journals Requiring Review for } \\
\text { Potential Dual-Use }\end{array}$ & \% Respondents (N) \\
\hline All of the journals & $0 \%$ \\
\hline Most of the journals & $11 \%$ \\
\hline Some of the journals & $13 \%$ \\
\hline A few of the journals & $17 \%$ \\
\hline None of the journals & $17 \%$ \\
\hline Don't know & $43 \% \quad(20)$ \\
\hline Total & $100 \% \quad(47)$ \\
\hline
\end{tabular}

Opinions about scientific journal and professional society responsibilities. A large proportion of respondents agree that "Scientific journals should have guidelines regarding publication of dual-use research" (Question 30) and that "Professional societies should have codes for the responsible conduct of dual-use life sciences research" (Question 32).

\begin{tabular}{|c|c|c|c|c|c|}
\hline \multicolumn{6}{|c|}{$\begin{array}{l}\text { Questions 30-32. Scientific Journal and Professional Society Guidelines and Codes of } \\
\text { Conduct }\end{array}$} \\
\hline 30: & \multicolumn{5}{|c|}{$\begin{array}{l}\text { Scientific journals should have guidelines regarding publication of dual- } \\
\text { use research. }\end{array}$} \\
\hline Strongly Agree & Agree & $\begin{array}{l}\text { Neutral/ } \\
\text { No Opinion }\end{array}$ & Disagree & $\begin{array}{l}\text { Strongly } \\
\text { Disagree }\end{array}$ & Total \\
\hline $23 \%(11)$ & $60 \%(28)$ & $9 \%(4)$ & $6 \%(3)$ & $2 \%(1)$ & $100 \%(47)$ \\
\hline \multicolumn{6}{|c|}{ [no 31 in web survey] } \\
\hline 32: & \multicolumn{5}{|c|}{$\begin{array}{l}\text { Professional science societies should have codes for the responsible } \\
\text { conduct of dual-use life sciences research. }\end{array}$} \\
\hline Strongly Agree & Agree & $\begin{array}{l}\text { Neutral/ } \\
\text { No Opinion }\end{array}$ & Disagree & $\begin{array}{l}\text { Strongly } \\
\text { Disagree }\end{array}$ & Total \\
\hline $32 \%(15)$ & $51 \%$ & $11 \%$ & $4 \%(2)$ & $2 \%(1)$ & $100 \%(47)$ \\
\hline
\end{tabular}

Professional society membership .Few respondents are members of professional societies that have codes of responsible conduct for dual-use research (18\%) and nearly one-half did not know whether the societies in which they are members have this type of conduct codes. 


\begin{tabular}{|c|c|}
\hline $\begin{array}{l}\text { Question 34: Member of Professional Science Societies } \\
\text { with Codes of Conduct }\end{array}$ & $\%$ Respondents (N) \\
\hline Yes & $18 \%$ \\
\hline No & $38 \% \quad(17)$ \\
\hline Don't Know & $44 \% \quad(20)$ \\
\hline Total & $100 \% \quad(45)$ \\
\hline
\end{tabular}

\section{B.5 Minimizing Potential Threat to National Security (Questions 38-61)}

In Questions 38-61 of the survey, respondents were asked to evaluate "possible actions that could be taken to minimize the potential threat to national security that may be posed by knowledge, tools, or techniques from dual-use research." Opinions were requested regarding several areas-Roles and Responsibilities of Scientists, Access to Agents and Equipment, Research Findings, Training, and Review and Funding.

Role and responsibilities of scientists. Respondents generally believe that it is the responsibility of the scientists to evaluate dual-use potential of their research and to assure their institution of this assessment (Questions 38-39). Requiring scientists to take an oath (Question 40) or obtain certification (Question 41) were considered to be less likely to minimize the potential threat to national security, but there was some support for these options. There was also some disagreement about whether greater Federal oversight would reduce risk (Question 42) - 60\% disagreed, but more than one-quarter of the respondents thought that it would reduce risk.

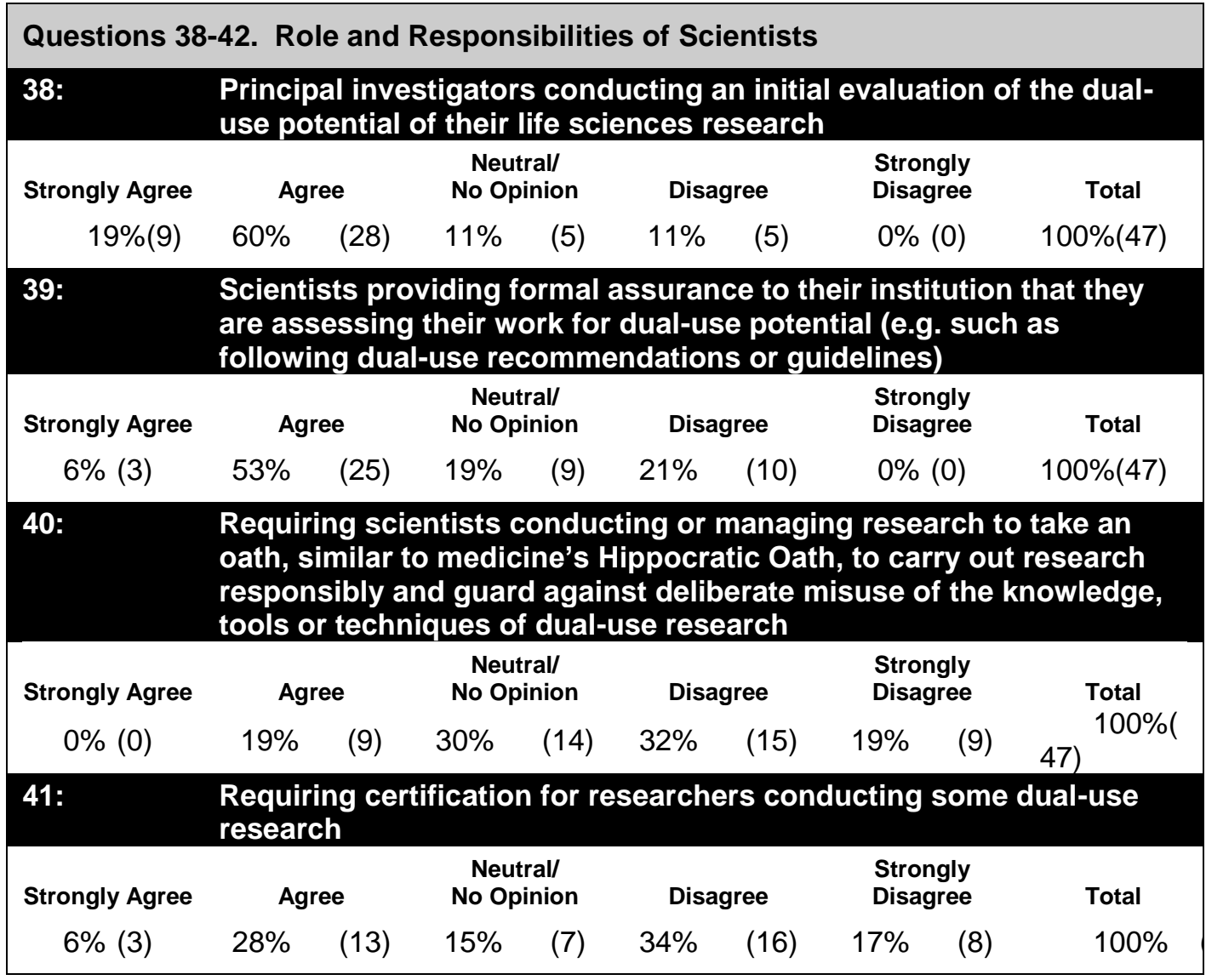




\section{Questions 38-42. Role and Responsibilities of Scientists}

\section{2: $\quad$ Providing greater federal oversight of dual-use research}

\begin{tabular}{|c|c|c|c|c|c|c|c|c|c|}
\hline Strongly Agree & & & $\begin{array}{l}\text { Neu } \\
\text { No Op }\end{array}$ & & Dis & & $\begin{array}{l}\text { Strc } \\
\text { Dise }\end{array}$ & & Total \\
\hline $0 \%(0)$ & $28 \%$ & (13) & $11 \%$ & (5) & $43 \%$ & (20) & $17 \%$ & (8) & $100 \%$ \\
\hline
\end{tabular}

Access to agents and equipment. There is little agreement in the opinions about whether placing greater restrictions on access to specific biological agents or toxins would minimize the potential threat to national security (Question 45). About one-half of the respondents agree, while the other half disagrees. A majority of respondents $(66 \%)$ believes that requiring licensure of certain biological equipment would not minimize potential threat.

\begin{tabular}{|c|c|c|c|c|c|}
\hline 45: & \multicolumn{5}{|c|}{$\begin{array}{l}\text { Placing greater restrictions on access to specific biological agents } \\
\text { or toxins }\end{array}$} \\
\hline Strongly Agree & Agree & $\begin{array}{l}\text { Neutral/ } \\
\text { No Opinion }\end{array}$ & Disagree & $\begin{array}{l}\text { Strongly } \\
\text { Disagree }\end{array}$ & Total \\
\hline $11 \%(5)$ & $34 \%(16)$ & $13 \%(6)$ & $32 \%(15)$ & $11 \%(5)$ & $\begin{array}{r}100 \% \\
(47)\end{array}$ \\
\hline 46: & \multicolumn{5}{|c|}{$\begin{array}{l}\text { Requiring licensure of certain biological equipment that is } \\
\text { commonly used in life science research }\end{array}$} \\
\hline Strongly Agree & Agree & $\begin{array}{l}\text { Neutral/ } \\
\text { No Opinion }\end{array}$ & Disagree & $\begin{array}{l}\text { Strongly } \\
\text { Disagree }\end{array}$ & Total \\
\hline $2 \%(1)$ & $19 \%(9)$ & $13 \%(6)$ & $38 \%(18)$ & $28 \%(13)$ & $100 \%$ \\
\hline
\end{tabular}

Research findings. Questions 49-52 ask respondents whether actions related to research findings would minimize potential threat to national security. Responses are varied in this area, with about $20 \%$ of respondents having neutral or no opinions on these actions, and the rest of the responses relatively split between "disagree" and "agree." There appears to be no pattern across groups, except that a larger percentage of respondents who took the 2006 Outreach and Education Training agreed with Question 49 (12 out of 26 , or $45 \%$ ) versus those who did not take the training ( 5 out of 20 , or $25 \%$ ). 


\begin{tabular}{|c|c|c|c|c|c|}
\hline \multicolumn{6}{|c|}{ Questions 49-52. Research Findings } \\
\hline 49: & \multicolumn{5}{|c|}{$\begin{array}{l}\text { Placing restrictions on disclosure of details about the research or its } \\
\text { findings through personal communication }\end{array}$} \\
\hline $\begin{array}{l}\text { Strongly } \\
\text { Agree }\end{array}$ & Agree & $\begin{array}{l}\text { Neutral// } \\
\text { No Opinion }\end{array}$ & Disagree & $\begin{array}{l}\text { Strongly } \\
\text { Disagree }\end{array}$ & \multirow{2}{*}{$\begin{array}{l}\text { Total } \\
100 \% \\
(46)\end{array}$} \\
\hline $0 \%(0)$ & $37 \%(17)$ & $24 \%(11)$ & $24 \%(11)$ & $15 \%(7)$ & \\
\hline 50 & \multicolumn{5}{|c|}{$\begin{array}{l}\text { Altering or removing certain experimental methods or findings prior } \\
\text { to publication or presentation }\end{array}$} \\
\hline $\begin{array}{l}\text { Strongly } \\
\text { Agree }\end{array}$ & Agree & $\begin{array}{l}\text { Neutral/ } \\
\text { No Opinion }\end{array}$ & Disagree & $\begin{array}{l}\text { Strongly } \\
\text { Disagree }\end{array}$ & \multirow{2}{*}{$\begin{array}{l}\text { Total } \\
100 \% \\
(46)\end{array}$} \\
\hline $2 \%(1)$ & $43 \%(20)$ & $15 \%(7)$ & $22 \%(10)$ & $17 \%(8)$ & \\
\hline 51: & \multicolumn{5}{|c|}{$\begin{array}{l}\text { Placing restrictions on publication of findings based on dual-use } \\
\text { potential }\end{array}$} \\
\hline $\begin{array}{l}\text { Strongly } \\
\text { Agree }\end{array}$ & Agree & $\begin{array}{l}\text { Neutral/ } \\
\text { No Opinion }\end{array}$ & Disagree & $\begin{array}{l}\text { Strongly } \\
\text { Disagree }\end{array}$ & \multirow{2}{*}{$\begin{array}{l}\text { Total } \\
100 \% \\
(47)\end{array}$} \\
\hline $0 \%(0)$ & $36 \%(17)$ & $23 \%(11)$ & $28 \%(13)$ & $13 \%(6)$ & \\
\hline 52: & \multicolumn{5}{|c|}{ Classifying research findings on dual-use potential } \\
\hline $\begin{array}{l}\text { Strongly } \\
\text { Agree }\end{array}$ & Agree & $\begin{array}{l}\text { Neutral/ } \\
\text { No Opinion }\end{array}$ & Disagree & $\begin{array}{l}\text { Strongly } \\
\text { Disagree }\end{array}$ & \multirow{2}{*}{$\begin{array}{l}\text { Total } \\
100 \% \\
(45)\end{array}$} \\
\hline $4 \%(2)$ & $42 \%(19)$ & $22 \%(10)$ & $13 \%(6)$ & $18 \%(8)$ & \\
\hline
\end{tabular}

Training. The majority agrees that training about dual-use research, policies, and practices would minimize the potential threat to national security, especially training laboratory staff, students, and visiting scientists (Questions 55-56). At least one-half of the respondents believe that threat to national security would be minimized if institutions provided mandatory training for scientists, while nearly $25 \%$ had neutral or no opinion regarding this action and $26 \%$ disagreed.

\begin{tabular}{|c|c|c|c|c|c|}
\hline \multicolumn{6}{|c|}{ Questions 55-57. Training } \\
\hline 55: & \multicolumn{5}{|c|}{$\begin{array}{l}\text { Principal investigators providing training to lab staff, students and } \\
\text { visiting scientists about dual-use research including policies and } \\
\text { practices to minimize the potential for misuse of information from } \\
\text { their research. }\end{array}$} \\
\hline $\begin{array}{l}\text { Strongly } \\
\text { Agree }\end{array}$ & Agree & $\begin{array}{c}\text { Neutral/ } \\
\text { No Opinion }\end{array}$ & Disagree & $\begin{array}{l}\text { Strongly } \\
\text { Disagree }\end{array}$ & \\
\hline $11 \%(5)$ & $65 \%(30)$ & $7 \%(3)$ & $15 \%(7)$ & $2 \%(1)$ & $\begin{array}{c}100 \% \\
(46)\end{array}$ \\
\hline 56: & \multicolumn{5}{|c|}{$\begin{array}{l}\text { University and college students receiving educational lectures and } \\
\text { materials on dual-use life sciences research including the potential } \\
\text { that knowledge, tools and techniques of such research that could } \\
\text { pose a threat to national security. }\end{array}$} \\
\hline $\begin{array}{l}\text { Strongly } \\
\text { Agree }\end{array}$ & Agree & $\begin{array}{c}\text { Neutral/ } \\
\text { No Opinion }\end{array}$ & Disagree & $\begin{array}{l}\text { Strongly } \\
\text { Disagree }\end{array}$ & Total \\
\hline $11 \%(5)$ & $63 \%(29)$ & $13 \%(6)$ & $13 \%(6)$ & & $\begin{array}{c}100 \% \\
(46)\end{array}$ \\
\hline
\end{tabular}




\begin{tabular}{|c|c|c|c|c|c|}
\hline \multicolumn{6}{|c|}{ Questions 55-57. Training } \\
\hline 57: & \multicolumn{5}{|c|}{$\begin{array}{l}\text { Institutions providing mandatory training for scientists regarding } \\
\text { dual-use life sciences research. }\end{array}$} \\
\hline $\begin{array}{l}\text { Strongly } \\
\text { Agree }\end{array}$ & Agree & $\begin{array}{l}\text { Neutral/ } \\
\text { No Opinion }\end{array}$ & Disagree & $\begin{array}{l}\text { Strongly } \\
\text { Disagree }\end{array}$ & Total \\
\hline $11 \%(5)$ & $40 \%(18)$ & $24 \%(11)$ & $\begin{array}{r}22 \% \\
(10) \\
\end{array}$ & $4 \%(2)$ & $\begin{array}{c}100 \% \\
(46)\end{array}$ \\
\hline
\end{tabular}

Review and funding. Requiring review of proposals for dual-use potential prior to submission received mixed results $-47 \%$ agreed that this would help minimize potential threat to national security and $43 \%$ disagreed. While the majority of respondents $(62 \%)$ agreed that requiring grantees to attest that dual-use implications were considered when applying for grants would help minimize potential threat, more than $25 \%$ disagreed.

\begin{tabular}{|c|c|c|c|c|c|}
\hline \multicolumn{6}{|c|}{ Questions 60-61: Review and Funding } \\
\hline 60. & \multicolumn{5}{|c|}{$\begin{array}{l}\text { Reviewing all grant proposals for life sciences research with dual- } \\
\text { use potential by an appropriate individual or board (such as an IBC) } \\
\text { at a researcher's institution prior to submission for funding. }\end{array}$} \\
\hline $\begin{array}{l}\text { Strongly } \\
\text { Agree }\end{array}$ & Agree & $\begin{array}{c}\text { Neutral/ } \\
\text { No Opinion }\end{array}$ & Disagree & $\begin{array}{l}\text { Strongly } \\
\text { Disagree }\end{array}$ & Total \\
\hline & $38 \%(18)$ & $11 \%(5)$ & $\begin{array}{r}30 \% \\
(14)\end{array}$ & & $\begin{array}{c}100 \% \\
(47)\end{array}$ \\
\hline 61. & \multicolumn{5}{|c|}{$\begin{array}{l}\text { Funding agencies requiring grantees to attest on grant applications } \\
\text { that they have considered dual-use implications of their proposed } \\
\text { research. }\end{array}$} \\
\hline $\begin{array}{l}\text { Strongly } \\
\text { Agree }\end{array}$ & Agree & $\begin{array}{c}\text { Neutral/ } \\
\text { No Opinion }\end{array}$ & Disagree & $\begin{array}{l}\text { Strongly } \\
\text { Disagree }\end{array}$ & Total \\
\hline $15 \%(7)$ & $47 \%(22)$ & $11 \%(5)$ & $\begin{array}{l}21 \% \\
(10) \\
\end{array}$ & $6 \%(3)$ & $\begin{array}{c}100 \% \\
(47) \\
\end{array}$ \\
\hline
\end{tabular}

Opinions about bioterrorism and dual-use research. More respondents disagreed than agreed that "Funding agencies would be less likely to fund grant proposals if the proposed research had dual-use potential." However, almost one-third of respondents were neutral or had no opinion and more than onequarter of respondents at least agreed with the statement.

\begin{tabular}{|c|c|c|c|c|c|}
\hline Question 64. & $\begin{array}{l}\text { Funding a } \\
\text { proposed }\end{array}$ & $\begin{array}{l}\text { es would } \\
\text { rch had d }\end{array}$ & se po & no gran & Is if the \\
\hline $\begin{array}{l}\text { Strongly } \\
\text { Agree }\end{array}$ & Agree & $\begin{array}{c}\text { Neutral/ } \\
\text { No Opinion }\end{array}$ & Dis & $\begin{array}{l}\text { Strongly } \\
\text { Disagree }\end{array}$ & \\
\hline $2 \%(1)$ & $24 \%(11)$ & $30 \%(14)$ & $\begin{array}{l}39 \% \\
(18)\end{array}$ & $4 \%(2)$ & $\begin{array}{c}100 \% \\
(46) \\
\end{array}$ \\
\hline
\end{tabular}

In Questions 66 and 67, respondents indicated the percent chance that an act of bioterrorism would occur somewhere in the next 5 years. Respondents believe the risk is greater "in the world" than "in the United States." 


\begin{tabular}{|lccc|}
\hline \multicolumn{2}{|c|}{ Questions 66-67: Percent Chance of Bioterrorism } & & \\
\hline & Mean & Median & Range \\
66. In the world & $57 \%$ & $50 \%$ & $2 \%-100 \%$ \\
67. In the United States & $37 \%$ & $25 \%$ & $1 \%-100 \%$ \\
\hline
\end{tabular}

One-half of the respondents believe that there is at least a $25 \%$ chance "that knowledge, tools or techniques from dual-use life sciences research will facilitate an act of bioterrorism somewhere in the world in the next five years."

\begin{tabular}{|lccc|}
\hline \multicolumn{2}{|c|}{ Question 68: Percent Chance Bioterrorism Facilitated by Dual-Use Research } \\
\hline $\begin{array}{l}\text { 68. Percent chance that knowledge, tools } \\
\text { or techniques from dual-use life } \\
\text { sciences research will facilitate an act } \\
\text { of bioterrorism somewhere in the world } \\
\text { in the next five years. }\end{array}$ & $31 \%$ & $25 \%$ & Reange \\
\hline
\end{tabular}

The results to Questions 70-73 indicate that the means of communication that have a greater ability to provide sufficient information for an individual with college-level life science training to deliberately create a harmful biological agent are scientific journal articles and internet.

\begin{tabular}{llccc|}
\hline $\begin{array}{l}\text { Questions 70-73: Means of Communication Sufficient Sources for Creation of } \\
\text { Harmful Biological Agent }\end{array}$ & Yes & No & Don't Know & Total \\
& $64 \%$ & $19 \%$ & $17 \%$ & $100 \%$ \\
70. Scientific journal articles & $(30)$ & $(9)$ & $(8)$ & $(47)$ \\
71. Presentations at scientific & $40 \%$ & $49 \%$ & $11 \%$ & $100 \%$ \\
conferences or meetings & $(19)$ & $(23)$ & $(5)$ & \\
72. Personal communications & $49 \%$ & $26 \%$ & $26 \%$ & $100 \%$ \\
(e.g., e-mail, phone calls) & $(23)$ & $(12)$ & $(12)$ & \\
73. Internet & $77 \%$ & $11 \%$ & $13 \%$ & $100 \%$ \\
\hline
\end{tabular}

\section{B.6 Respondent Background}

Most of the respondents (68\%) have doctorate degrees or the equivalent.

\begin{tabular}{llrr|}
\hline Question 76: Highest Educational Degree Awarded & $\%$ Respondents (N) \\
\hline Bachelor's degree or equivalent (e.g., BS, BA, AB) & $4 \%$ & $(2)$ \\
Master's degree or equivalent (e.g., MS, MA, MBA, etc.) & $17 \%$ & $(8)$ \\
Doctorate or equivalent (e.g., PhD, DSc, EdD, etc.) & $68 \%$ & $(32)$ \\
Other professional degree (e.g., JD, LLB, MD, DDS, DVM, & $6 \%$ & $(3)$ \\
etc.) & $4 \%$ & $(2)$ \\
Joint doctorate and professional degree (e.g. Ph.D. and MD) & $0 \%$ & $(0)$ \\
Other & Total & $\mathbf{1 0 0} \%$ & $(\mathbf{4 7})$ \\
\hline
\end{tabular}


The year that the highest degree was awarded ranged from 1969 to 2007.

\begin{tabular}{|lccc|}
\hline Question 77: Year Highest Educational Degree Awarded & & \\
\hline & Mean & Median & Range \\
\hline $\begin{array}{c}\text { 77. In what year was your highest } \\
\text { educational degree awarded? }\end{array}$ & 1987 & 1985 & $1969-2007$ \\
\hline
\end{tabular}

Primary areas of work or study vary across respondents. Respondents represented the areas listed below.

\begin{tabular}{|l|}
\hline Question 78: Primary Scientific Discipline \\
\hline Biochemistry \\
Biodefense \\
Bioinformatics \\
Biological Safety/Security \\
Biomedical Engineering \\
Biotechnology \\
Cell Biology \\
Chemistry \\
Geology/Soil Sciences/Geography \\
Health Physics \\
Immunology \\
Life Sciences \\
Medicine \\
Microbiology \\
Molecular Biology \\
Nanotechnology \\
Oceanography \\
Physics \\
Risk Analysis \\
\hline
\end{tabular}

The respondents' roles are varied, with the largest group being Senior Research Scientists (43\%).

\begin{tabular}{|c|c|}
\hline Question 80: Current Role & $\%$ Respondents (N \\
\hline Senior Research Scientist & $43 \% \quad(18)$ \\
\hline Mid-level Research Scientist & $17 \%$ \\
\hline Junior Scientist & $0 \%$ \\
\hline Program/Project Manager & $19 \%$ \\
\hline Laboratory Manager & $10 \%$ \\
\hline Research associate/technician & $0 \%$ \\
\hline $\begin{array}{l}\text { Other (including Biological Safety Officer, Research Ops } \\
\text { Manager, PostDoc, and Institutional Board Members) }\end{array}$ & $12 \%$ \\
\hline Total & $100 \% \quad(42)$ \\
\hline
\end{tabular}





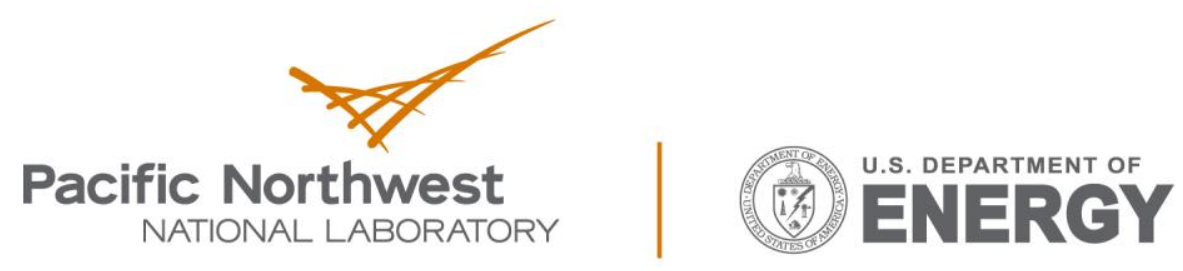

Proudly Operated by Battelle Since 1965

902 Battelle Boulevard

P.O. Box 999

Richland, WA 99352

1-888-375-PNNL (7665)

www.pnnl.gov 